\title{
Bertumbuhnya Penduduk Bali Pasca-Reformasi (1998)
}

\author{
I Wayan Sudana \\ Dinas Kependudukan, Pencatatan Sipil \\ dan Keluarga Berencana Provinsi Bali \\ email: wyn.sudana888@gmail.com
}

\begin{abstract}
Population is a capital in a development of a country but on the other side, it is also a problem for the development if the population is not well managed. A big amount of population will be potential to provide human resources. Such a big amount will be a great market for the domestic production but it will need the provision of foods, shirts, houses, jobs, and facilities of education, health, etc. This thing happens in Bali because this island is an international popular destination. In the post-reform (reformasi Indonesia), Bali population growth in 1998 has increased. This is caused by several factors, namely: TFR increase, positive net migration, and decreased mortality. There are many potential negative impacts that can arise because of the population problems due to the increase in the rate of growth. Therefore, in development, the population must be paid more attention, because in essence in the development of the population is as the subject and object. The development should be able to improve the welfare of the inhabitants either inborn or in a just and sustainable way.
\end{abstract}

Keywords: post-Reform, Bali population, migrant, TFR, IMR.

\section{PENDAHULUAN}

Penduduk merupakan modal pembangunan, tetapi ia juga menjadi masalah dalam kelangsungan pembangunan apabila tidak direncanakan dan dikelola secara benar. Penduduk dalam jumlah besar berarti potensi yang besar dalam hal ketersediaan sumber daya manusia (SDM). Selain itu, penduduk dalam jumlah besar juga merupakan pangsa pasar yang besar bagi hasil produksi domestik. Namun penduduk dalam jumlah besar juga menuntut ketersediaan sandang, pangan, papan (perumahan), lapangan kerja, dan fasilitas (sarana dan prasarana pendidikan, kesehatan, dll).

Hampir semua perencanaan pembangunan perlu ditunjang data kependudukan. Semakin lengkap dan akurat data kependudukan yang tersedia 
makin mudah dan tepat rencana pembangunan itu dibuat. Bali sangat didukung oleh sektor pariwisata, baik itu wisata alam maupun budaya. Maka dari itu, dalam perkembangannya Bali tidak terlepas dari prinsip-prinsip yang dipegang teguh oleh masyarakatnya seperti konsep tri hita karana, yaitu hubungan manusia dengan manusia, hubungan manusia dengan alam dan hubungan manusia dengan Tuhan.

Terkait dengan hal demikian maka jumlah penduduk yang ideal secara normatif adalah yang memenuhi aspek-aspek kesejahteraan individu, keseimbangan dengan lingkungan, dan kekayaan spiritual. Penanganan kependudukan dari sisi demografi hanyalah bagian dari suatu masalah dalam mencapai keadaan penduduk yang diinginkan secara kuantitas, akan tetapi jumlah penduduk yang ideal hanya tercapai apabila ketiga aspek tersebut bisa terpenuhi.

Pertumbuhan penduduk Bali pasca-Reformasi (tahun 1998) mengalami kenaikan. Hal ini dikarenakan oleh kenaikan nilai TFR, adanya migrasi netto positif, ditambah lagi dengan tingkat kematian yang menurun pada saat itu.

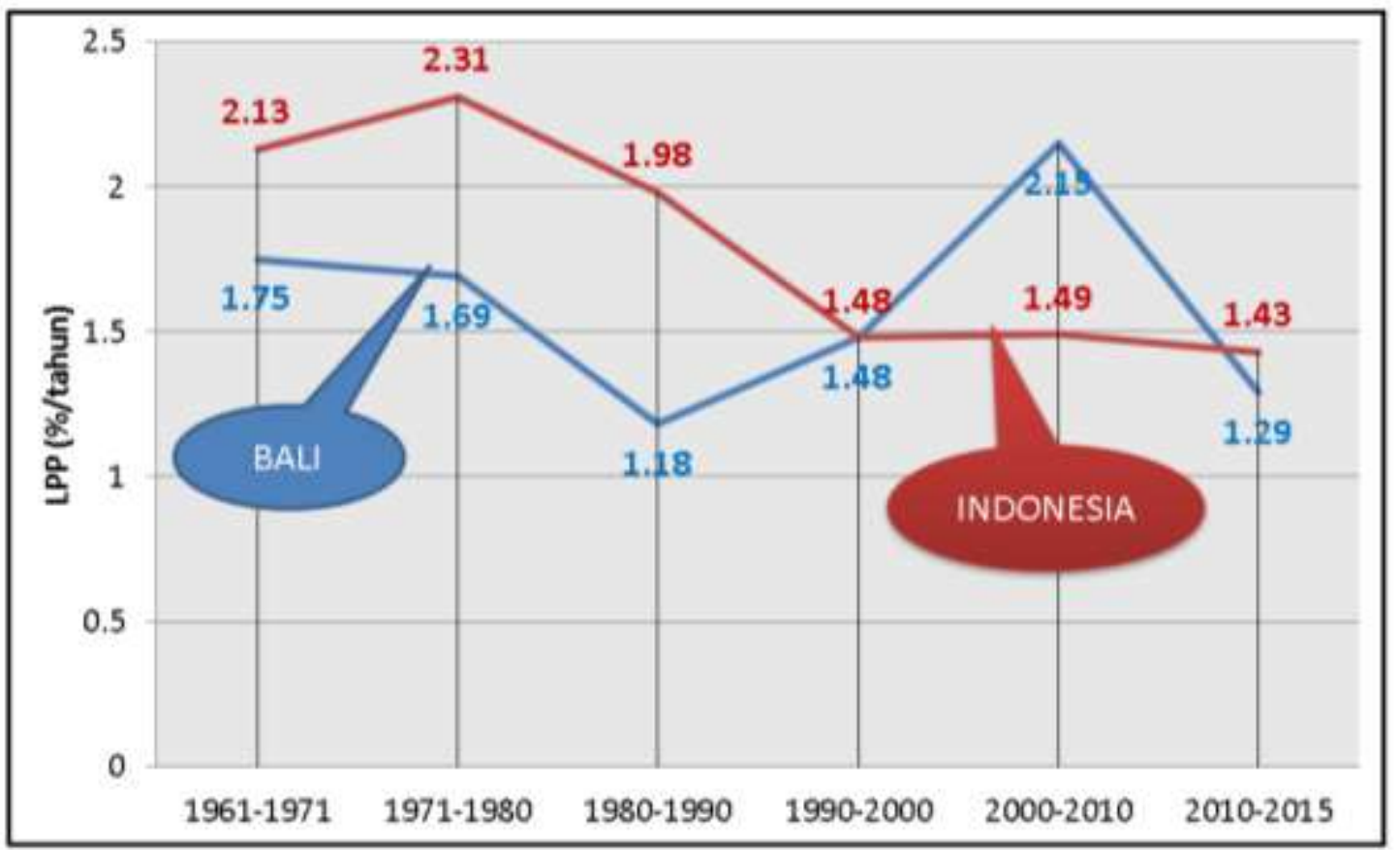

Grafik 1

Laju Pertumbuhan Penduduk (LPP) Provinsi Bali pada Tahun 1961-2015 
Grafik 1 (LPP Provinsi Bali Tahun 1961-2015) menunjukkan laju pertumbuhan penduduk Indonesia yang menurun sejak tahun 1971 hingga tahun 2000, dan hanya mengalami sedikit peningkatan LPP pada tahun 20002010 dan kembali menurun pada tahun 2010-2015. Hal ini sangat berbeda dengan LPP Provinsi Bali pada pasca-Reformasi (tahun 1998) yang mengalami kenaikan tinggi. Padahal sebelumnya mengalami penurunan pada masa Orde Baru pada tahun 1990.

\section{PEMBAHASAN}

Pertumbuhan penduduk tidak selamanya memberikan hal yang positif untuk pertumbuhan aspek lain. Jika tidak ditangani dengan baik maka pertumbuhan penduduk yang diluar kendali bisa mengakibatkan banyaknya kerugian untuk negara

Pembangunan suatu bangsa berkaitan erat dengan permasalahan kependudukannya. Suatu pembangunan dapat berhasil jika didukung oleh subjek pembangunan, yakni penduduk yang memiliki kualitas dan kuantitas yang memadai. Pertumbuhan penduduk di Bali sangat berkaitan dengan permasalahan kependudukan di Indonesia.
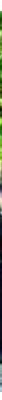

\section{Permasalahan Kuantitas Penduduk dan Dampaknya dalam Pembangunan}

Jumlah penduduk yang besar berdampak langsung terhadap pembangunan berupa tersedianya tenaga kerja yang sangat diperlukan dalam pelaksanaan pembangunan. Akan tetapi kuantitas penduduk tersebut juga memicu munculnya permasalahan yang berdampak terhadap pembangunan. Permasalahan-permasalahan tersebut di antaranya: 
- Pesatnya pertumbuhan penduduk yang tidak diimbangi dengan kemampuan produksi menyebabkan tingginya beban pembangunan berkaitan dengan penyediaan pangan, sandang, dan papan.

- Kepadatan penduduk yang tidak merata menyebabkan pembangunan hanya terpusat pada daerah-daerah tertentu yang padat penduduknya saja. Hal ini menyebabkan hasil pembangunan tidak bisa dinikmati secara merata, sehingga menimbulkan kesenjangan sosial antara daerah yang padat dan daerah yang jarang penduduknya.

- Tingginya angka urbanisasi menyebabkan munculnya kawasan kumuh di kota-kota besar, sehingga menimbulkan kesenjangan sosial antara kelompok kaya dan kelompok miskin kota.

- Pesatnya pertumbuhan penduduk yang tidak seimbang dengan volume pekerjaan menyebabkan terjadinya pengangguran yang berdampak pada kerawanan sosial.

\section{Permasalahan Kualitas Penduduk dan Dampaknya terhadap Pembangunan}

Berbagai permasalahan yang berkaitan dengan kualitas penduduk dan dampaknya terhadap pembangunan adalah sebagai berikut.

Pertama, masalah tingkat pendidikan. Keadaan penduduk di negaranegara yang sedang berkembang tingkat pendidikannya relatif lebih rendah dibandingkan penduduk di negara-negara maju, demikian juga dengan tingkat pendidikan penduduk Indonesia. Rendahnya tingkat pendidikan penduduk Indonesia disebabkan oleh tingkat kesadaran masyarakat untuk bersekolah rendah, besarnya anak usia sekolah yang tidak seimbang dengan penyediaan sarana Pendidikan, serta pendapatan perkapita penduduk di Indonesia yang rendah.

Dampak yang ditimbulkan dari rendahnya tingkat pendidikan terhadap pembangunan sebagai betikut. (1) Rendahnya penguasaan teknologi maju, sehingga harus mendatangkan tenaga ahli dari negara maju. Keadaan ini sungguh ironis, dimana keadaan jumlah penduduk Indonesia besar, tetapi tidak mampu mencukupi kebutuhan tenaga ahli yang sangat diperlukan dalam 
pembangunan. (2) Rendahnya tingkat pendidikan mengakibatkan sulitnya masyarakat menerima hal-hal yang baru. Hal ini nampak dengan ketidakmampuan masyarakat merawat hasil pembangunan secara benar, sehingga banyak fasilitas umum yang rusak karena ketidakmampuan masyarakat memperlakukan secara tepat. Kenyataan seperti ini apabila terus dibiarkan akan menghambat jalannya pembangunan. Oleh karena itu, pemerintah mengambil beberapa kebijakan yang dapat meningkatkan mutu pendidikan masyarakat.

Kedua, masalah kesehatan. Tingkat kesehatan suatu negara umumnya dilihat dari besar kecilnya angka kematian, karena kematian erat kaitannya dengan kualitas kesehatan.

Kualitas kesehatan yang rendah umumnya disebabkan oleh kurangnya sarana dan pelayanan kesehatan, kurangnya air bersih untuk kebutuhan seharihari, kurangnya pengetahuan tentang kesehatan, gizi yang rendah, Penyakit menular, dan lingkungan yang tidak sehat (lingkungan kumuh).

Dampak rendahnya tingkat kesehatan terhadap pembangunan adalah terhambatnya pembangunan fisik karena perhatian tercurah pada perbaikan kesehatan yang lebih utama karena menyangkut jiwa manusia. Selain itu, jika tingkat kesehatan manusia sebagai objek dan subjek pembangunan rendah, maka dalam melakukan apa pun khususnya pada saat bekerja, hasilnya pun akan tidak optimal.

Ketiga, masalah tingkat penghasilan/pendapatan. Tingkat penghasilan/pendapatan suatu negara biasanya diukur dari pendapatan per kapita, yaitu jumlah pendapatan rata-rata penduduk dalam suatu negara.

Negara-negara berkembang umumnya mempunyai pendapatan per kapita rendah, Berdasarkan pendapatan per kapitanya, negara digolongkan menjadi 3, yaitu:

1. Negara kaya, pendapatan per kapitanya > US\$1.000.

2. Negara sedang, pendapatan per kapitanya $=$ US\$300-1.00.

3. Negara miskin, pendapatan per kapitanya < US\$300. 
Untuk meningkatkan pendapatan masyarakat (kesejahteraan masyarakat), sehingga dapat mendukung lancarnya pelaksanaan pembangunan pemerintah melakukan upaya dalam bentuk:

1. Menekan laju pertumbuhan penduduk.

2. Merangsang kemauan berwiraswasta.

3. Menggiatkan usaha kerajinan rumah tangga/ industrialisasi.

4. Memperluas kesempatan kerja.

5. Meningkatkan GNP dengan cara meningkatkan barang dan jasa.

\section{Pertumbuhan Penduduk Bali Pasca-Reformasi}

Jumlah penduduk Bali semakin bertambah setiap tahunnya, sementara luas wilayah yang tidak berubah akan berakibat pada peningkatan kepadatan. Perkembangan laju pertumbuhan penduduk Bali mengalami penurunan sampai dengan periode tahun 1990 mencapai 1,18 persen per tahun, kemudian kembali meningkat menjadi 1,26 persen periode 1990-2000, dan akhirnya 2,15 persen per tahun dalam periode 2000-2010 pada saat memasuki era pascaReformasi.

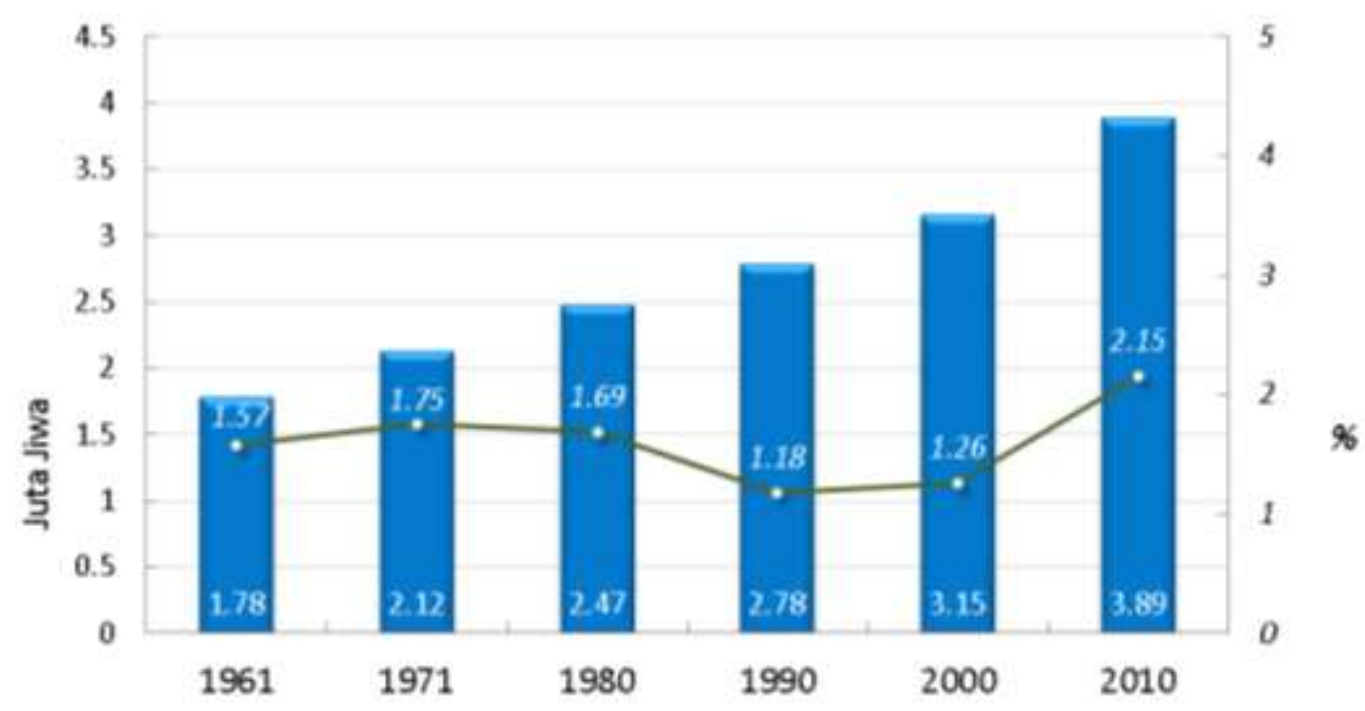

Jumlah Penduduk

--Laju Pertumbuhan

Penduduk

Grafik 2

Jumlah dan Laju Provinsi Bali pada Tahun 1961-2015 
Bali mengalami momentum pertumbuhan penduduk yang tersembunyi, yaitu pertambahan penduduk mempunyai kecenderungan untuk terus melaju, seolah-olah laju pertumbuhan penduduk tersebut mengandung suatu daya gerak (momentum) internal yang kuat dan tersembunyi. Perbandingan komposisi dan jumlah penduduk Provinsi Bali dari Tahun 1990-2010 pada Gambar 1 tentang komposisi dan jumlah penduduk Provinsi Bali Tahun 19902000 dan Gambar 2 tentang komposisi dan jumlah penduduk Provinsi Bali tahun 2010.

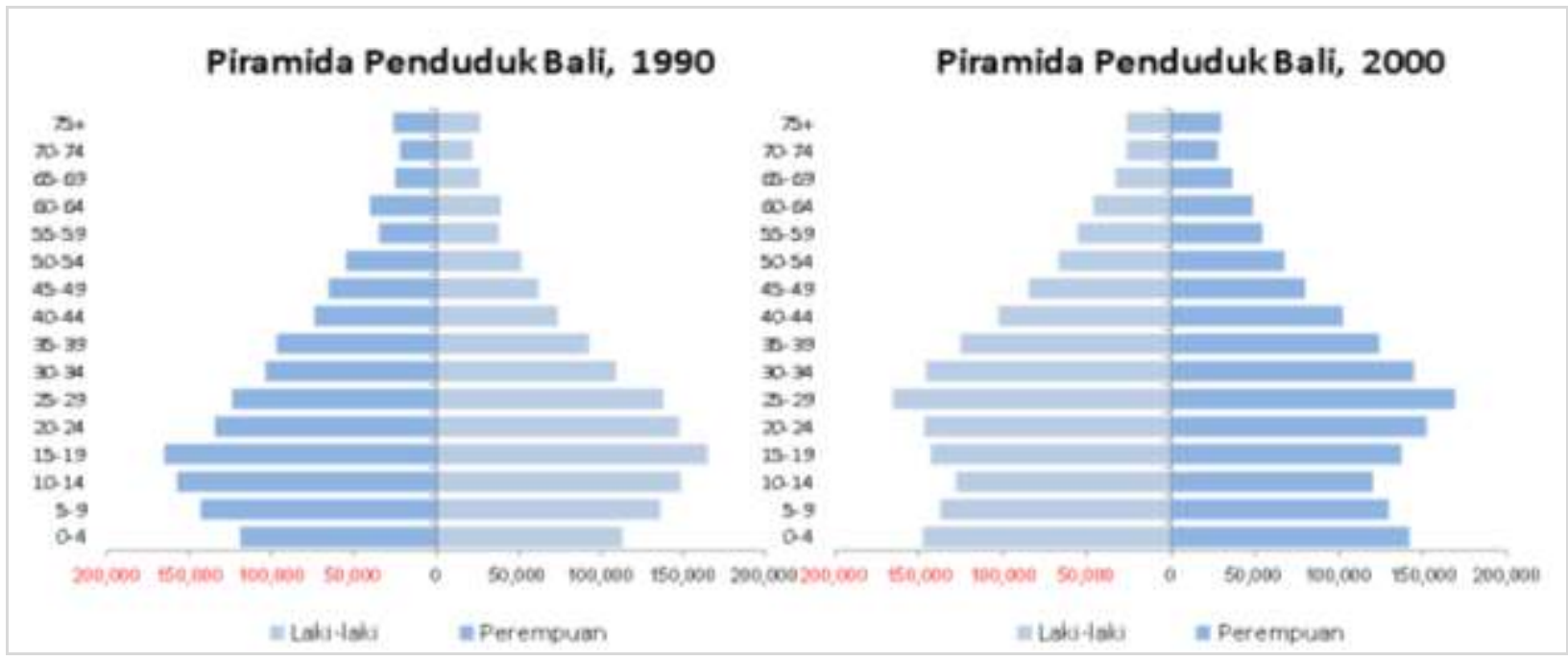

Gambar 1

Komposisi dan Jumlah Penduduk Provinsi Bali Tahun 1990-2000.

Piramida Penduduk Bali, 2010

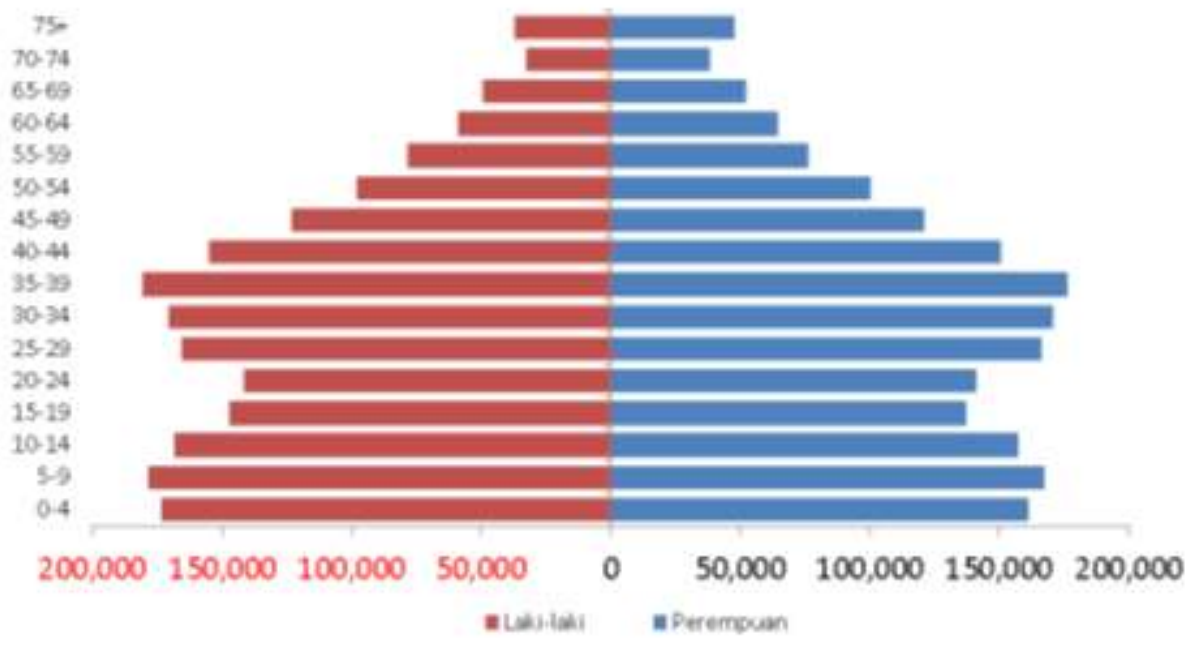

Gambar 2

Komposisi dan Jumlah Penduduk Provinsi Bali Tahun 2010. 


\section{Faktor Penyebab Laju Pertumbuhan Penduduk yang Tinggi Pasca-}

\section{Reformasi}
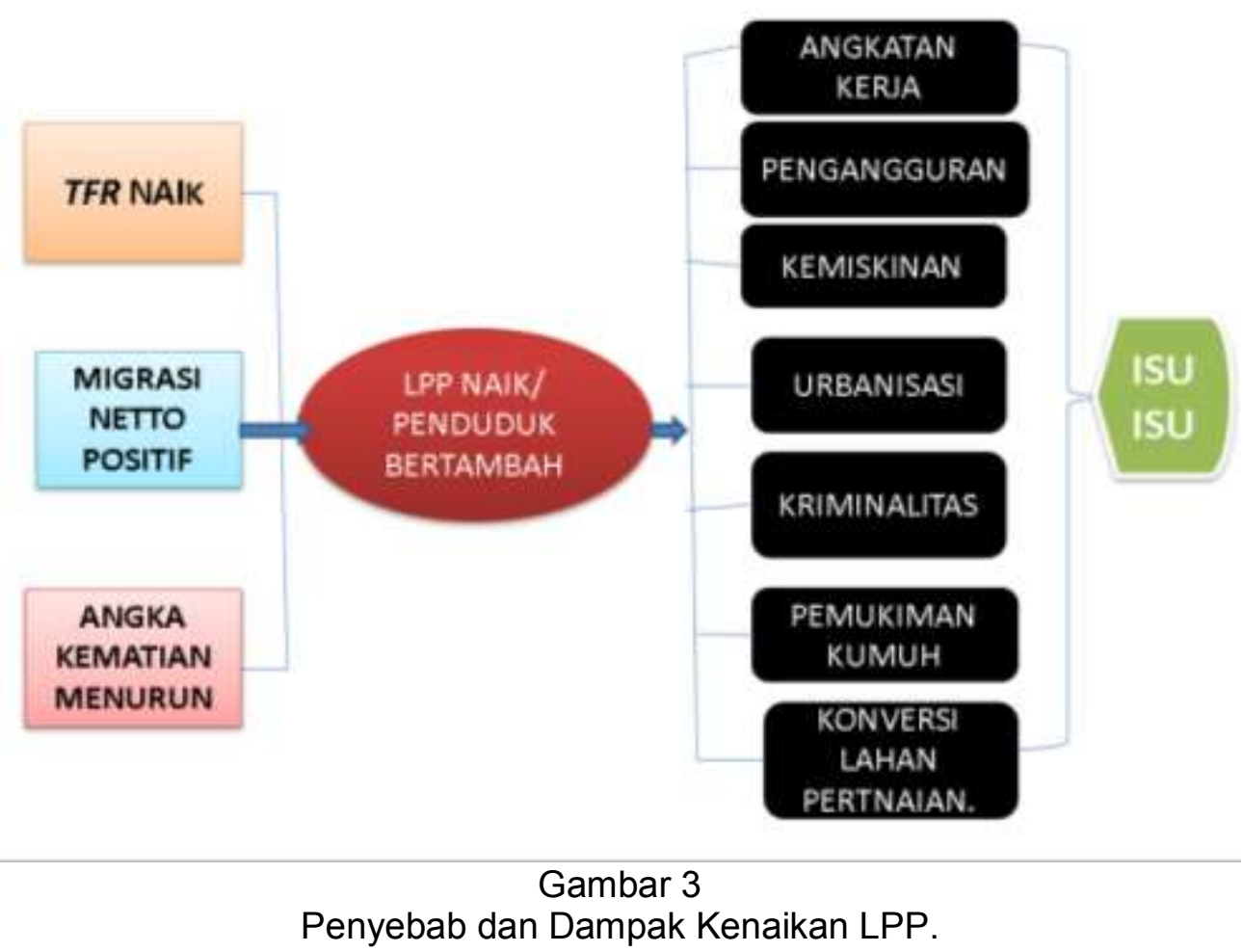

Kenaikan laju pertumbuhan penduduk (LPP) mengakibatkan pertambahan jumlah penduduk. Kenaikan LPP terjadi dikarenakan oleh beberapa faktor berikut.

Pertama, TFR Naik: Total Fertility Rate (TFR) adalah jumlah anak ratarata yang akan dilahirkan oleh seorang perempuan pada akhir masa reproduksinya apabila perempuan tersebut mengikuti pola fertilitas pada saat TFR dihitung. Trend TFR berdasarkan kelompok usia dapat dilihat pada Grafik 3 (Trend ASFR Penduduk Bali Berdasarkan Periode dan Total Trend TFR) dapat dilihat pada Grafik 4 (Trend TFR Penduduk Bali Berdasarkan Periode). 


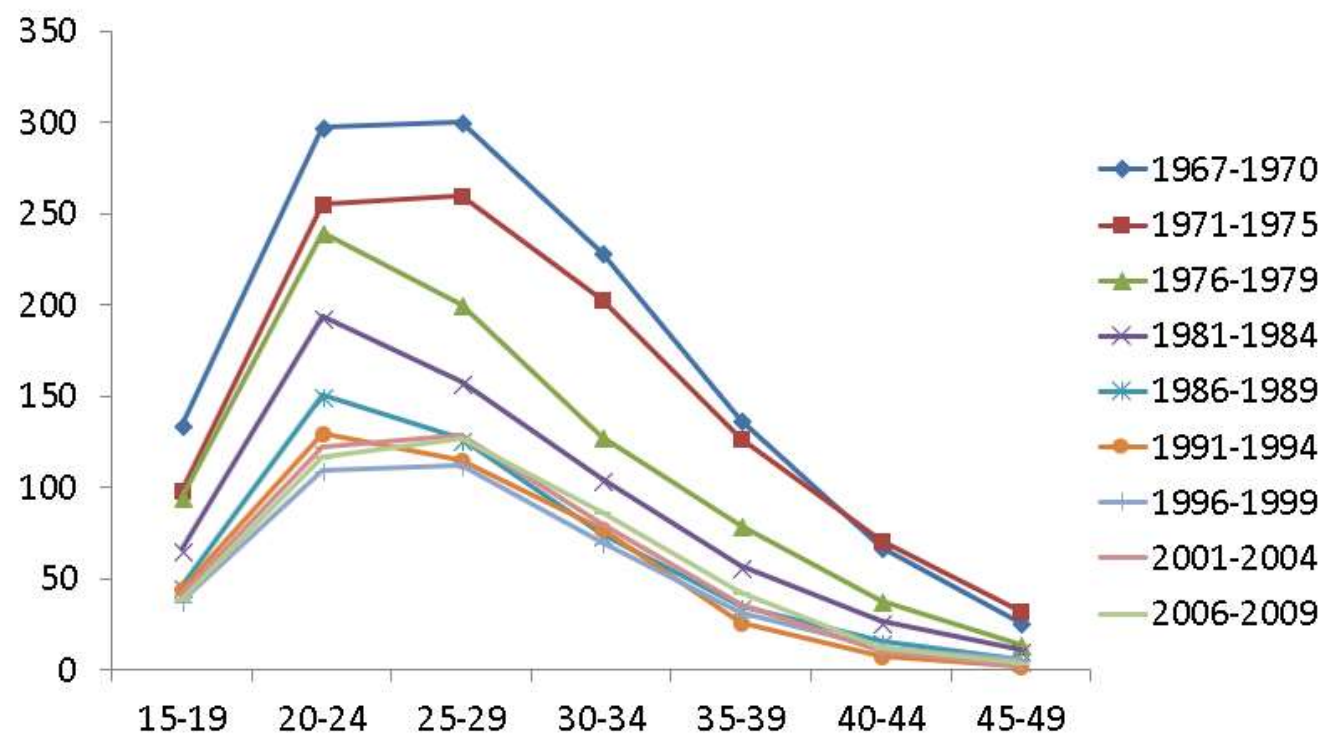

Grafik 3 Trend ASFR Penduduk Bali Berdasarkan Periode.

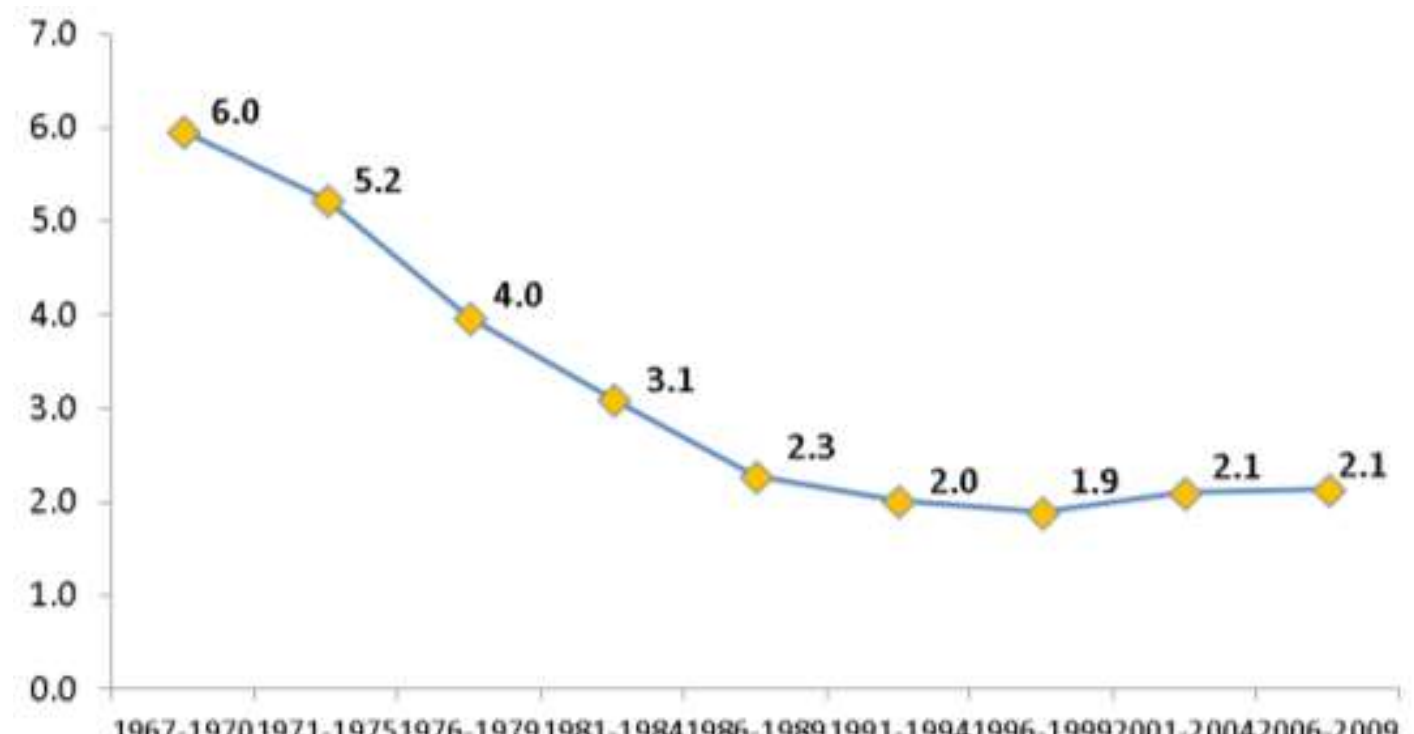

Grafik 4

Trend TFR Penduduk Bali Berdasarkan Periode.

Grafik 4 menunjukkan tren TFR yang mengalami kenaikan pascaReformasi Tahun 1998 setelah adanya penurunan yang signifikan sejak tahun 1967. 
Kedua, migrasi netto positif.
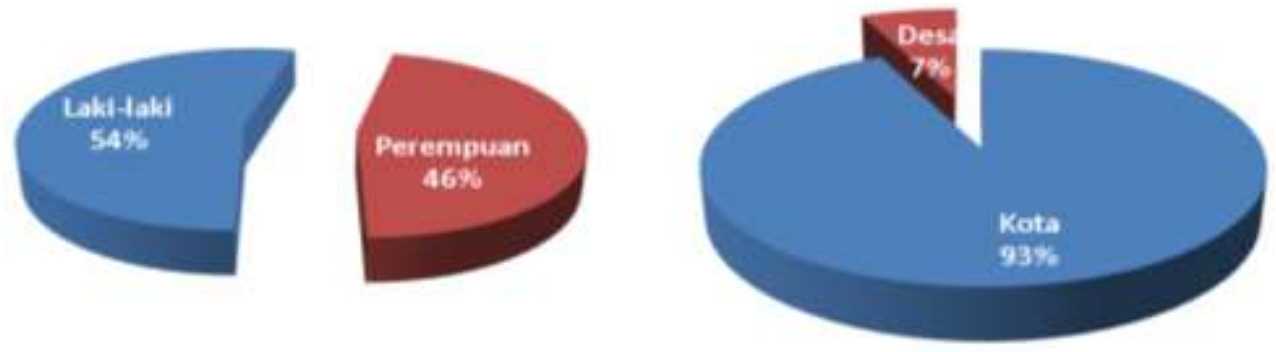

Bagan 1

Persentase Lifetime in Migrant ke Bali menurut Jenis Kelamin dan Tempat Tinggal, Provinsi Bali, 2010

Sebesar 93 persen migran lebih memilih untuk tinggal di daerah perkotaan dan hanya 7 persen yang tinggal di daerah perdesaan. Kemungkinan sebagai akibat dari daya tarik perkotaan dengan segala kemudahan dan kelengakapan fasilitas. Perlu dipikirkan segala dampak konsentrasi migran di perkotaan. Selain migrasi di desa ke kota yang ada di Provinsi Bali, terjadi pula migrasi dari Provinsi lain ke Bali karena pada pasca-Reformasi banyak penduduk yang mencari daerah tempat tinggal yang aman dan memiliki lapangan pekerjaan. Migrasi kembalinya migran ke daerah asal kemungkinan terjadi pada tahun 2010-2015, dimana masyrarakat telah kembali percaya akan keamanan daerah asalnya. Hal ini terlihat pada penurunan laju pertumbuhan penduduk di Provinsi Bali setelah tahun 2010. Gambaran Migrasi yang masuk ke Bali menurut Kabupaten Kota dapat dilihat pada Grafik 5. 


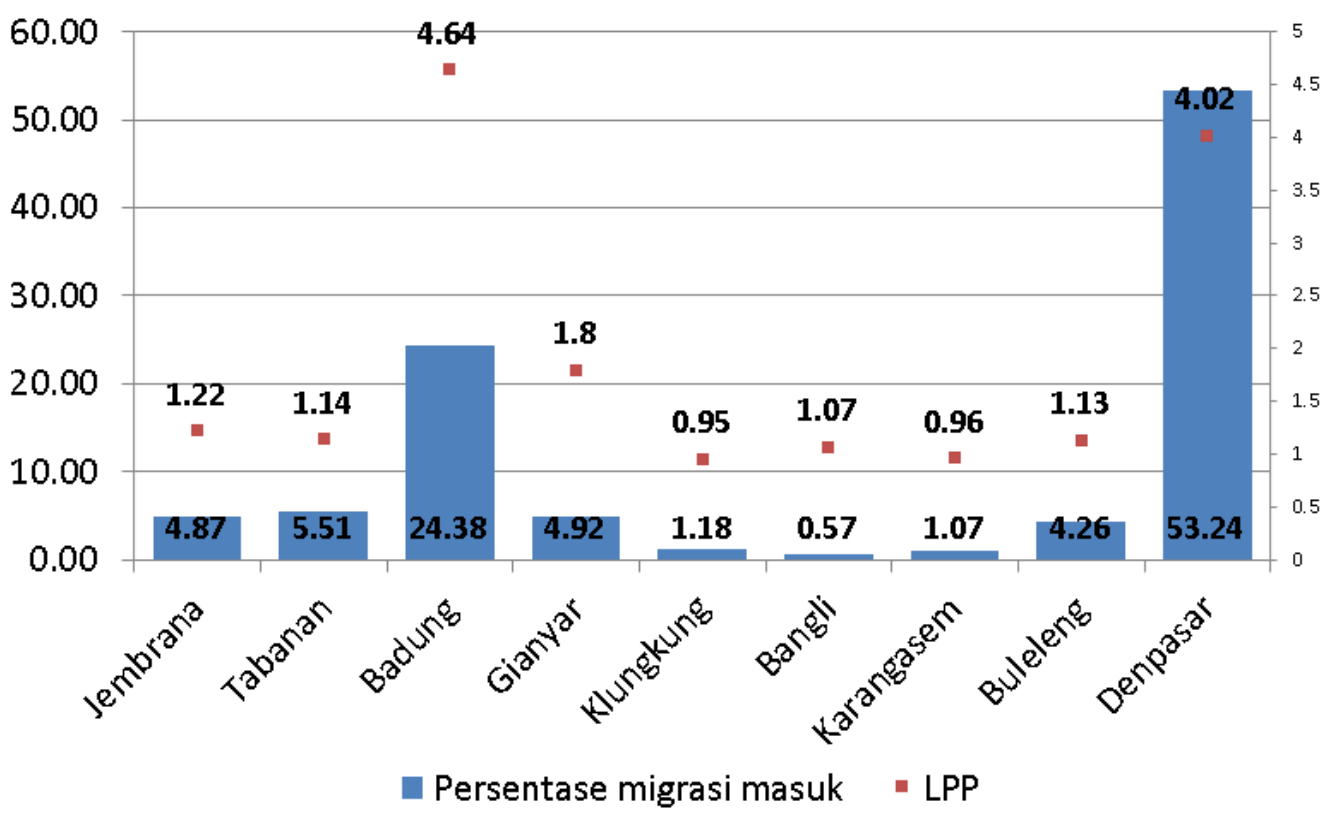

Grafik 5

Laju Pertumbuhan Penduduk dan Migrasi Masuk ke Bali Seumur Hidup menurut Kabupaten/Kota, Provinsi Bali 2010

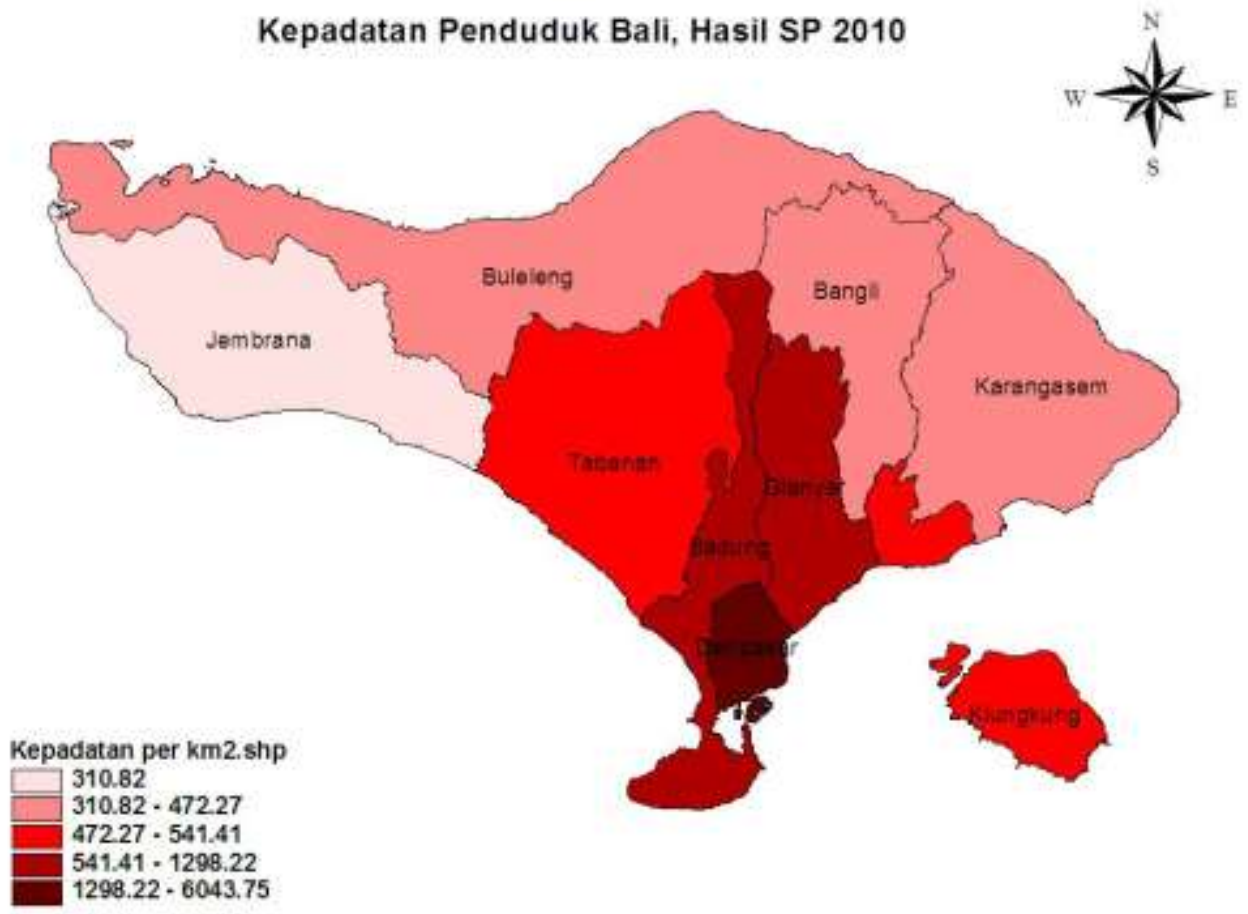

Gambar 4

Kepadatan Penduduk Provinsi Bali 2010, hasil SP 2010. 
Tabel 1

Distribusi dan Kepadatan Penduduk per Kabupaten/Kota, Provinsi Bali, 2000-2010

\begin{tabular}{l|cc|c|c|}
\hline KABUPATEN/KOTA & \multicolumn{3}{|c|}{ JUMLAH PENDUDUK } & KEPADATAN PENDUDUK \\
(ORANG/KM PERSEG)
\end{tabular}

Tabel 1 menunjukkan penyebaran penduduk di kabupaten/kota yang tidak merata. Kepadatan terjadi di Denpasar, Gianyar, dan Badung. Hal ini berbanding lurus dengan migrasi masuk yang terjadi di Kabupaten/Kota Provinsi Bali.

Berdasarkan Data Agregat Kependudukan Provinsi Bali Semester 2 Tahun 2017, telah terjadi perubahan penyebaran penduduk. Data menunjukkan bahwa Kabupaten Buleleng memiliki jumlah penduduk tertinggi yaitu 816.654 orang, dengan persentase 19,34 dari total jumlah penduduk Provinsi Bali.

Tabel 2

Data Agregat Kependudukan Provinsi Bali Semester 2 Tahun 2017

\begin{tabular}{|c|c|c|c|c|c|}
\hline \multirow{2}{*}{ Kabupaten/Kota } & \multicolumn{2}{|c|}{ Laki-Laki } & \multicolumn{2}{|c|}{ Perempuan } & \multirow{2}{*}{ Jumlah } \\
\hline & $\mathbf{n}$ & $\%$ & $\mathbf{n}$ & $\%$ & \\
\hline 5101-Jembrana & 162.207 & 3,84 & 162.040 & 3,84 & 324.24 \\
\hline 5102-Tabanan & 222.984 & 5,28 & 218.073 & 5,17 & 441.05 \\
\hline 5103-Badung & 235.562 & 5,58 & 235.636 & 5,58 & 471.19 \\
\hline 5104-Gianyar & 247.578 & 5,86 & 247.742 & 5,87 & 495.32 \\
\hline 5105-Klungkung & 107.661 & 2,55 & 109.783 & 2,60 & 217.44 \\
\hline 5106-Bangli & 133.051 & 3,15 & 132.329 & 3,13 & 265.38 \\
\hline 5107-Karangasem & 275.911 & 6,54 & 272.341 & 6,45 & 548.25 \\
\hline 5108-Buleleng & 408.788 & 9,68 & 407.866 & 9,66 & 816.65 \\
\hline 5171-Denpasar & 321.395 & 7,61 & 320.497 & 7,59 & 641.89 \\
\hline Total Provinsi & 2.115 .1 & 50,1 & 2.106 .3 & 49,9 & 4.221. \\
\hline
\end{tabular}




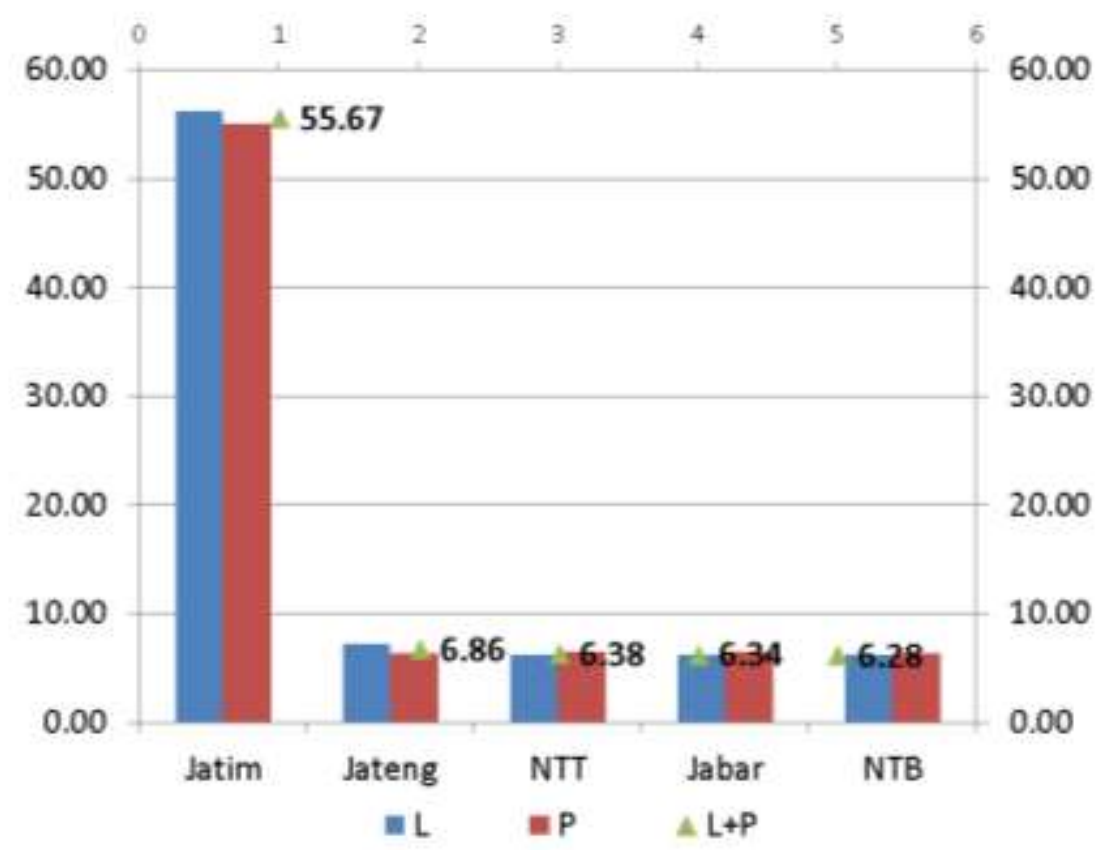

Grafik 6

Provinsi Penyumbang Migran Risen Terbesar ke Bali

Penyumbang Migran Risen Terbesar ke Bali yang ditunjukan pada Grafik 6 adalah berasal dari Provinsi Jawa Timur. Hal ini dikarenakan letak geografis Provinsi Jawa Timur yang berdekatan dengan Provinsi Bali sehingga memudahkan masyarakatnya melakukan migrasi.

Ketiga, Angka Kematian Menurun: Angka kematian bayi (IMR) menggambarkan jumlah kematian bayi berumur kurang dari satu tahun per 1000 kelahiran hidup pada satu tahun tertentu. Selama empat dasawarsa terakhir, tingkat mortalitas yang diwakili oleh IMR cenderung mengalami penurunan yang cukup signifikan. Hal ini disebabkan oleh semakin meningkatnya fasilitas kesehatan yang menunjang kesehatan bayi dan anakanak. 


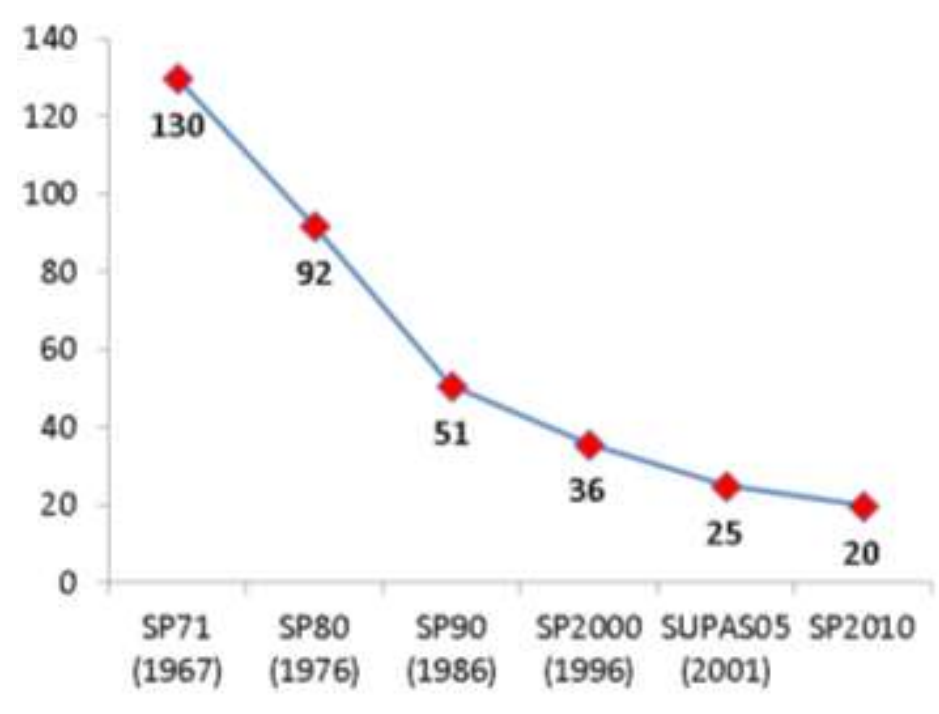

Grafik 7

Infant Mortality Rate (IMR) Provinsi Bali 1967-2010

\section{PENUTUP}

Pertumbuhan penduduk pasca-Reformasi Tahun 1998 mengalami kenaikan. Hal ini disebabkan oleh beberapa faktor, yaitu: kenaikan TFR, migrasi netto positif, dan menurunnya angka kematian. Banyak sekali potensi dampak negatif yang dapat muncul karena masalah kependudukan akibat dari kenaikan laju pertumbuhan tersebut. Mulai dari bertambahnya pengangguran, kemiskinan, urbanisasi, kriminalitas, pemukiman kumuh, hingga terjadinya konversi lahan pertanian. Oleh karena itu dalam pembangunan, penduduk harus mendapat perhatian utama, karena pada hakekatnya dalam pembangunan penduduk adalah sebagai subyek dan obyek. Pembangunan harus mampu meningkatkan kesejahteraan penduduk baik lahir ataupun batin secara berkeadilan dan berkelanjutan.

\section{DAFTAR PUSTAKA}

Badan Pusat Statistik Provinsi Bali. 2012. Perkembangan Kependudukan Hasil Sensus Penduduk Tahun 2010.

Dayuh Rimbawan, Nyoman. 2018. "Koalisi Kependudukan Provinsi Bali. Inventarisasi Isu-Isu Strategis Dampak Kependudukan”, Denpasar,19 April.

Dinas Kependudukan, Pencatatan Sipil, dan Keluarga Berencana Provinsi Bali. 2017. Buku Data Agregat Kependudukan Provinsi Bali Semester 2 Tahun 2017. Denpasar. 
Bertumbuhnya Penduduk Bali Pasca-Reformasi (1998) dan Faktor-faktor Penyebabnya | 123

Dinas Kependudukan, Pencatatan Sipil, dan Keluarga Berencana Provinsi Bali. 2017. Profil Perkembangan Kependudukan Provinsi Bali Tahun 2016.

Sugiharsono, dkk. 2008. Contextual Teaching and Learning IImu Pengetahuan Sosial: Sekolah Menengah Pertama/Madrasah Tsanawiyah Kelas VIII Edisi 4. Jakarta. Pusat Perbukuan Departemen Pendidikan Nasional. 
